Piotr Daszkiewicz

Paryż-Warszawa

Philippe Edel

Strasbourg

\title{
Poszukiwanie egzemplarzy Anatome testudinis europaeae w europejskich i amerykańskich bibliotekach
}

Wydana w Wilnie w 80 egzemplarzach w latach 1819-1821 przez Ludwika Henryka Bojanusa (Ludwig Heinrich, 1776-1827) dwutomowa monografia anatomii żółwia błotnego Anatome testudinis europaeae... ${ }^{1}$ była jedną z najważniejszych publikacji dziewiętnastowiecznej zoologii. Georges Cuvier (1769-1832) uznał nawet, że dzięki tej pracy żółw błotny stał się najlepiej poznanym z punktu widzenia anatomii gatunkiem i że żadna monograficzna książka z dziedziny anatomii nie dorównuje doskonałością tej rozprawie $^{2}$. Podobną opinię wyrażało wielu dziewiętnastowiecznych przyrodników, m.in. uznawani za wspóltwórców nowoczesnej herpetologii André Marie Constant Dumeril (1774-1860) i Georges Bibron (1806-1848)³.

Po dzień dzisiejszy pozycja ta wzbudza zainteresowanie zarówno przyrodników jak i historyków nauki ${ }^{4}$, a także księgoznawców. Monografię wydano w Niemczech w 1902 r. ${ }^{5}$ i w Stanach Zjednoczonych w 1970 r. ${ }^{6}$ Jej autor, wybitny zoolog, wileński profesor, twórca weterynarii na ziemiach dawnej Rzeczypospolitej, L.H. Bojanus przeprowadził sekcje około 500

1 Zob. L.H. Bojanus, Anatome Testudinis Europaeae Accedunt Tabulae XXXI, Quarum IX Duplici Exemplo, t. 1-2, Vilnae: Impensis auctoris, typis Josephi Zawadzki..., 1819-1821.

2 Zob. G. Cuvier, Histoire des sciences naturelles depuis leur origine jusqu'à nos jours. Troisième partie contenant la fin de la deuxième moitié du $18^{e}$ siècle et une partie du $19^{e}$, Paris 1845, s. 405.

3 Zob. A.M.C. Dumeril, G. Bibron, Erpétologie générale ou Histoire naturelle complète des reptiles, t. 1: Généralités de l'histoire des reptiles et celles de l'ordre des chéloniens ou des tortues, Paris 1834, s. 432-433.

4 Zob. P. Daszkiewicz, Some remarks about the origin and history of Bojanus Anatome Testudinis Europaeae. Herpetological Bulletin, „Bulletin of the British Herpetological Society” 2001, z. 75, s. 6-9.

5 Zob. L.H. Bojanus, Anatome testudinis europaeae: Vilnae 1819-1821, Berlin 1902.

6 Zob. Anatome testudinis europaeae. An anatomy of the turtle, Athens, Ohio 1970. 
żółwi błotnych, zastosował różne techniki anatomiczne i poświęcił dziesięć lat życia na przygotowanie rozprawy ${ }^{7}$. Aby móc ją opracować, sprowadził z Hesji do Wilna rytownika i drukarza Friedricha Leonharda Lehmanna $(1787-1835)^{8}$ i zakupił prasę drukarską. Historycy uznają, że to zoologiczna publikacja zapoczątkowała sztukę litografii na Litwie99.

Jakub Jakubowski uznaje Anatome testudinis europaeae za „jedną $\mathrm{z}$ ostatnich wielkich ilustrowanych książek polskiego Oświecenia” ${ }^{10}$. Autor ten podaje interesujące informacje na temat powstania tej pracy i historii sztuki drukarskiej:

W najbardziej wyczerpującej z polskich bibliografii prac Bojanusa [chodzi o publikację Zygmunta Fedorowicza - P.D., P.E.] możemy napotkać wzmiankę o wykonanym przez niego i opublikowanym w Wilnie w roku 1819 polskim tłumaczeniu francuskiego dziełka, poświęconego sztuce litograficznej: Wykład Sztuki litograficznej (przekład z francuskiego): czytane na sesji Uniwersytetu Wileńskiego (Wilno 1817). Jeżeli ta informacja bibliograficzna jest prawdziwa, mamy w tym przypadku do czynienia z pierwszym polskim wydaniem podręcznika litografii, czego nie odnotowano dotychczas w kluczowych opracowaniach poświęconych dziejom tej techniki graficznej w naszym kraju. Świadczyłoby to także o tym, że Bojanus u progu decyzji o publikacji swojego magnum opus [...], rozważał zastosowanie nowej wówczas metody druku do przeniesienia szkiców na strony książki. Ostatecznie zdecydował się jednak na wykonanie tablic w sprawdzonej technice miedziorytu, dominującej w naukowej książce oświeceniowej ${ }^{11}$.

Książka L.H. Bojanusa stanowiła niewątpliwie przełom w historii ilustracji przyrodniczej w tej części Europy. Zauważmy, że w innej pracy o żółwiu błotnym, powstałej na Litwie kilkadziesiąt lat wcześniej, autor Jean-Emmanuel Gilibert z braku innych materiałów wykorzystał miedzioryt z XVI w. przedstawiający... żółwia morskiego złowionego w Morzu Śródziemnym ${ }^{12}$. Zauważmy także wysoką jakość późniejszych ilustracji przyrodniczych

\footnotetext{
Zob. Z. Fedorowicz, Ludwik Henryk Bojanus, Warszawa-Wrocław 1958.

8 Na ten temat zob. m.in. P. Daszkiewicz, Plyty miedziane i miedzioryty Pierre Richer de Bellevala (1555-1632) w Rzeczpospolitej Obojga Narodów - z punktu widzenia historii botaniki, „Rocznik Polskiego Towarzystwa Dendrologicznego” 2013, Vol. 61, s. 74.

9 Uwaga recenzenta „Mimo prób podejmowanych przez Bojanusa, trudno uznać też, że «zoologiczna monografia zapoczątkowała sztukę litografii na Litwie», zwłaszcza, że ostatecznie w tym dziele użyto miedziorytów”.

10 J. Jakubowski, Dawna polska ilustrowana książka przyrodnicza (XVII-XIX wiek), „Acta Universitatis Wratislaviensis. Bibliotekoznawstwo” 2011, t. 30 (3392), s. 50-51.

11 Jak wyżej.

12 Zob. P. Daszkiewicz, A.M. Bauer, Jean-Emmanuel Gilibert and a Lost Chapter in the history of Chelonian Anatomy, „Bibliotheca Herpetologica” 2010, t. 2 (8), s. 6-19.
} 
tego samego wydawcy ${ }^{13}$ - np. przedstawiających gady w wydanej w latach 1836-1837 pracy Zoologia albo Historya naturalna źwierząt... Stanisława Batysa Gorskiego (1802-1864) i Norberta Alfonsa Kumelskiego (1802-1853).

L.H. Bojanus zadedykował swoje dzieło G. Cuvierowi, uznawanemu już wówczas za jednego z twórców nowoczesnej anatomii porównawczej, a zarazem jednemu z najbardziej wpływowych uczonych europejskich. W zbiorach rękopisów Biblioteki Głównej Narodowego Muzeum Historii Naturalnej (Muséum

13 Katalogi biblioteczne, np. elektroniczny BN w Warszawie - zob. [online] <http://alpha. bn.org.pl/search $\sim \mathrm{S} 5 * \mathrm{pol} /$ ?searchtype $=$ t\&searcharg $=$ Zoologia + albo+\&searchscope $=5 \&$ sortd ropdown $=-\&$ SORT $=$ D\&extended $=0 \&$ SUBMIT $=$ Szukaj\&searchlimits=\&searchorigarg $=$ tHistorya+naturalna+> (25.09.2016) identyfikują jako wydawcę trzech części Zoologii albo Historyi naturalnej źwierząt... Teofila Glücksberga (1796-1876). Nie odpowiada to stanowi faktycznemu. Biblioteka Główna Narodowego Muzeum Historii Naturalnej (MNHN) w Paryżu przechowuje egzemplarze trzech tomów książki (sygnatura 4843): Zoologia albo historyja naturalna źwierząt, w głównych zasadach, podług systematu Linneusza trybem Blumenbacha z wiela dodatków i odmian, zastosowanych do dzisiejszego stanu tej nauki dla użytku młodzieży szkolnej ułożona przez Norberta Alfona Kumelskiego, byłego Uniwersytetu Wileńskiego podbibliotekarza, następnie powołanego na profesora technologii powszechnej w tymże uniwersytecie, Cesarskiego Towarzystwa Badaczów natury w Moskwie i innych członka i Stanisława Batys Gorskiego w Cesarskiej Wileńskiej MedykoChirurgicznej Akademii w obowiazku adiunkta dającego farmakologia, farmacyja i botanikę. Dwa pierwsze tomy zostały wydane w Wilnie w 1836 r. „nakładem i drukiem Teofila Glücksberga, księgarza i typografa Cesarskiej, Med. Chir. Akad. i Białoruskiego Naukowego Okręgu”, natomiast tom trzeci ukazał się w Wilnie w 1837 r. „drukiem Józefa Zawadzkiego”. Tom pierwszy, oprócz wstępu zawierającego zarys historii zoologii i przedstawienie stosowanej przez autorów systematyki zoologicznej, poświęcony jest ssakom. Zawiera 230 stron numerowanego tekstu (właściwy tekst do strony 218, następnie - Spis alfabetyczny materyi w tej części zawartej) i dwie strony zatytułowane Omytki. Tom drugi - Ornitologia albo nauka o ptakach - kontynuuje numerację stron pierwszego tomu, rozpoczyna się od strony 221 (numeracja od 222) i kończy stroną 606 (właściwy tekst 221-581 i jedna strona Omytki druku). Tom trzeci - Erpetologia albo nauka o plazach - dotyczy płazów i gadów (te drugie wówczas zazwyczaj klasyfikowano jako płazy), rozpoczyna się sześciostronicową dedykacją „Jaśnie Wielmożnemu hrabiemu Konstantemu Tyzenhauzowi” (ten wybitny ziemianin, kolekcjoner, przyrodnik, mecenas sztuki i nauki, finansowo wspierał badania S.B. Gorskiego, który przekazywał mu swoje przyrodnicze obserwacje) zakończoną podpisem S.B. Gorskiego i datą „Wilno d. 8 maja 1837 r.” Tekst poświęcony opisom herpetofauny rozpoczyna się na stronie 583 (pierwsza numerowana - 284) i kończy stroną 868 oraz dodatkową Omyłki. To właśnie na końcu trzeciego tomu umieszczone są trzy ilustracje żmii zygzakowatej (ze względu na dużą kolorystyczną zmienność wewnątrzgatunkową opisywano wówczas różne formy kolorystyczne jako odrębne gatunki; na przedstawieniach widnieją: żmija czarna, żmija pstra i żmija ruda). Pod ilustracjami zamieszono informację: „w litograw. S. Oziębłowskiego”.

Pierwszy tom opatrzony jest rękopiśmienną dedykacją noszącą datę 20-29 listopada 1847 r., której fragment został ucięty (prawdopodbnie przy oprawianiu tomu): „Á Monsieur A. Valenciennes - Membre [de] l'Institut, professeur administrateur du Museum d'Histoire Naturelle, Chevalier de la [Leg]ion d'Honneur, etc. Comme preuve de sa plus grande estime l'Auteur” („Panu A. Valenciennes, Członkowi Instytutu, profesorowi administratorowi Muzeum Historii Naturalnej, Kawalerowi Legii Honorowej, itd. w dowodzie najwyższego uznania Autor”). Data dedykacji odpowiada okresowi podróży S.B. Gorskiego po Europie Zachodniej i prawdopodobnie jego pobytowi w Paryżu oraz wizycie w Narodowym Muzeum Historii Naturalnej. Achile Valenciennes (1794-1865), współpracownik G. Cuviera, wybitny parazytolog i ichtiolog, prawdopodobnie pomógł alzackiemu przyrodnikowi w badaniach prowadzonych przez niego w muzealnych zbiorach MNHN. 
National d'Histoire Naturelle) w Paryżu przechowywany jest list alzackiego przyrodnika do G. Cuviera z Wilna z 25 grudnia 1821 r. ${ }^{14}$, informujący o zadedykowaniu publikacji i motywacji tej decyzji. W liście L.H. Bojanus informuje także o wysłaniu dodatkowego egzemplarza książki, przeznaczonego dla Królewskiej Akademii Nauk w Paryżu.

Od kilkunastu lat towarzystwo Cercle d'Histoire Alsace-Lituanie w Strasbourgu prowadzi akcję mającą na celu przypomnienie i uczczenie pamięci tego alzackiego przyrodnika. Dzięki staraniom towarzystwa przeprowadzono poszukiwania w archiwach w Bouxwiller (rodzinnym mieście uczonego), Strasbourgu, Paryżu, Darmstadt i Wilnie, opublikowano kilka artykułów popularyzatorskich i ilustrowaną popularnonaukową biografię L.H. Bojanusa w serii „Portrety Alzacji”15 (wydanie litewskie jest przewidziane na jesień 2016 r.) oraz odsłonięto popiersie uczonego w Bouxwiller.

Poszukiwania przeprowadzone w archiwach nie tylko doprowadziły do wzbogacenia naszej wiedzy o życiu L.H. Bojanusa, lecz także dostarczyły szeregu informacji na temat książki, która odegrała tak istotną rolę w historii biologii. W archiwach w Darmstadt przechowywany jest, sporządzony po niemiecku, testament uczonego. Punkt 7 tego dokumentu stanowi:

Ostatnie rozliczenie za sprzedaż moich rycin anatomii żółwia pozostaje do odzyskania u księgarzy Fr [iedricha ${ }^{16}$ ] Fleischera w Lipsku i Fr[iedricha] Moritza $^{[17]} \mathrm{W}$ Wilnie, niesprzedane egzemplarze nakładu znajdują się częściowo u Fr. Fleischera, a częściowo tutaj u mnie, który posiada także $4 *$ odpowiadające miedzioryty, należy je wysłać do pana von Foriepa ${ }^{[18]}$, właściciela krajowego składu przemysłowego w Weimarze, po zawarciu wstępnej umowy, którą mam nadzieję uzgodnić jeszcze za życia, na skromną kwotę, która zostanie dorzucona do kapitału przeznaczonego dla mojej przybranej córki Amelii ${ }^{19}$.

14 Biblioteka Główna Narodowego Muzeum Historii Naturalnej w Paryżu (Bibliothèque centrale du MNHN), Ms 627, Lettre de Bojanus à Cuvier, s. 191-193.

15 Zob. P. Edel, P. Daszkiewicz, Louis Henri Bojanus. Le savant de Vilnius, Strasbourg 2015, s. 1-64.

16 Zob. Fleischer, Friedrich, [online] <https://www.deutsche-biographie.de/sfz16389.html> (03.12.2016).

17 Mowa o Fryderyku Morytzu - zob. R. Cybulski, Józef Zawadzki - księgarz, drukarz, wydawca, Wrocław 1972, s. 192.

18 Chodzi o Ludwiga Friedricha von Froriepa - zob. W. von Häfen, Ludwig Friedrich von Froriep (1779-1847). Ein Weimarer Verleger zwischen Ämtern, Geschäften und Politik, KölnWeimar-Wien 2007.

19 P. Daszkiewicz, P. Edel, Testament Ludwika Henryka Bojanusa (1776-1827), nieznany, interesujacy dokument historii nauk przyrodniczych - świadectwo ostatnich lat życia uczonego w Darmstadt, „Kwartalnik Historii Nauki i Techniki” 2013, nr 1, s. 119-124. Zob. też P. Daszkiewicz, P. Edel, The will of Ludwig Heinrich Bojanus (1776-1827), an interesting nineteenth-century natural history document, „Archives of Natural History” 2014, t. 41, nr 1, s. 164-167. 
Potwierdza to tezę Z. Fedorowicza, iż ogromne naukowe osiągnięcie nie stało się jednak sukcesem ekonomicznym ${ }^{20}$. Wydane jedynie w 80 egzemplarzach dzieło kosztowało pięć tysięcy rubli, które L.H. Bojanus wyłożył z własnej kieszeni. Jak wynika z testamentu, nawet ten niewielki nakład nie został sprzedany jeszcze w 1826 r., czyli siedem lat po wydaniu pierwszego tomu rozprawy.

Także listy odnalezione $\mathrm{w}$ archiwum firmy Merck $^{21}$, związanej rodzinnie z Bojanusem, dostarczyły nowych informacji na temat historii Anatome testudinis europaeae. W tym - kiedyś rodzinnym - zbiorze korespondencji L.H. Bojanusa przechowywany jest list księcia Adama Jerzego Czartoryskiego z 28 kwietnia 1822 r., który informował uczonego (jako kurator szkół wydziału wileńskiego), iż 17 kwietnia minister odebrał przesłany mu egzemplarz monografii i przekaże go carowi przy pierwszej dogodnej okazji. Jednocześnie zawiadamiał L.H. Bojanusa o odesłaniu mu poprzednio wysłanego „egzemplarza tegoż dzieła któren niebył [sic!] zupełny”. Dzięki tej wzmiance wiemy, iż część niewielkiego, przygotowanego tak wielkim wysiłkiem nakładu była wybrakowana. W świetle tej informacji interesującym byłoby odszukanie źródeł dotyczących rozliczeń L.H. Bojanusa z wileńskim drukarzem Józefem Zawadzkim (1781-1838)22. Dzieło zostało przecież wydane na koszt autora, a część nakładu - wydrukowana z defektami. Być może znalazło to odbicie w rozliczeniach między autorem a wydawcą? Przeprowadzone przez autorów artykułu poszukiwania w Wilnie i w Darmstadt niestety nie dostarczyły jak dotychczas żadnych danych na ten temat.

W okresie publikacji Anatome testudinis europaeae L.H. Bojanus pozostawał w otwartym konflikcie z wydawcą J. Zawadzkim² ${ }^{23}$. Podobnie jak inni profesorowie niemieckiego pochodzenia wspierał on F. Morytza, starającego się o zajęcie miejsca J. Zawadzkiego jako wydawcy i księgarza uniwersyteckiego. L.H. Bojanus był współautorem projektu, „,według którego Uniwersytet miał drukować podręczniki na własny koszt, zamiast księgarza zaś chcieli [autorzy projektu - P.D., P.E.] widzieć ekspedytora, urzędnika uniwersyteckiego" ${ }^{24}$. Nie wiadomo czy i w jakim stopniu konflikt ten wpłynął na wydawanie i dystrybucję książki. Zauważmy jednak, iż - jak wynika

20 Zob. Z. Fedorowicz, dz. cyt., s. 23.

21 Zob. P. Daszkiewicz, P. Edel, Korespondencja Ludwika Henryka Bojanusa (1776-1827) w archiwach firmy Merck w Darmstadt, „Kwartalnik Historii Nauki i Techniki” 2015, nr 3, s. 99100; P. Daszkiewicz, P. Edel, Nouvelles données sur l'histoire d'Anatome Testudinis Europaeae de Ludwig Heinrich Bojanus (1776-1827), „Bulletin de la Société Herpétologique de France” 2016, z. 158, s. 13-16.

22 Autorzy dziękują prof. Jackowi Puchalskiemu za zwrócenie uwagi na ten aspekt historii, jak i za wskazanie niemieckich bibliotek posiadających egzemplarze Anatome testudinis europaeae.

23 Zob. R. Cybulski, dz. cyt., s. 188-203.

24 Tamże, s. 198-199. 
z cytowanego powyżej testamentu L.H. Bojanusa - w Wilnie kolportażem zajmował się właśnie F. Morytz, konkurent J. Zawadzkiego. Przyrodnik najprawdopodobniej pozbawił zatem wydawcę ewentualnych zysków ze sprzedaży książki. Podkreślmy jednakże, że swoją kolejną pracę, Parergon ad L.H. Bojani Anatomen testudinis, wydał także u J. Zawadzkiego.

Jednym z elementów prowadzonej przez Cercle d'Histoire Alsace-Lituanie akcji upamiętniania L.H. Bojanusa jest inwentaryzacja zachowanych w bibliotekach egzemplarzy Anatome testudinis europaeae, wraz z próbą odtworzenia ich historii. Zauważmy, że stworzono już podobne rejestry w odniesieniu do innych prac przyrodniczych związanych z Rzeczypospolitą. Auricka Rickiene z Wilna zlokalizowała w europejskich bibliotekach egzemplarze Exercitia phytologica... J.-E. Giliberta ${ }^{25}$. Rozsyłanie formularzy z zapytaniem o egzemplarze dzieła alzackiego uczonego rozpocznie się na początku 2017 r. Autorzy liczą także, iż w poszukiwaniach pomoże zamieszczenie informacji o inwentaryzacji w czasopismach przyrodniczych i bibliologicznych. Jej podsumowanie przewidziane jest na 2019 r. Planuje się ponadto zorganizowanie wystawy upamiętniającej dwusetną rocznicę wydania tej rozprawy.

Formularze rozsyłane w dwujęzycznej (francuskiej i angielskiej) wersji zawierają pytania na temat wydania posiadanego egzemplarza (1819 r. - pierwszy tom wydany w Wilnie, 1821 r. - drugi tom wydany w Wilnie, 1819-1821 - oba tomy opublikowane tamże, 1902 r. - Berlin, 1970 r. - Athens/Ohio-USA), daty nabycia, poprzedniego właściciela, ekslibrisów, stempli, dedykacji, ewentualnych odręcznych zapisków, stanu egzemplarza i innych uwag.

Choć rozsyłanie ankiety jeszcze się nie rozpoczęło, to jednak autorzy uzyskali już szereg interesujących informacji na temat kilku „historycznych” egzemplarzy Anatome testudinis europaeae. Instytut Francuski (Institut de France) nadal przechowuje jeden z egzemplarzy przesłanych z Wilna G. Cuvierowi. W zbiorach tej instytucji znajduje się także jeden z listów L.H. Bojanusa do tego uczonego ${ }^{26}$. Narodowe Muzeum Historii Naturalnej w Paryżu ma w zbiorach Biblioteki Głównej oba tomy dzieła L.H. Bojanusa oraz dwa egzemplarze drugiego tomu (tekst objaśniający ilustracje) w bibliotece Laboratorium Gadów i Płazów i w Bibliotece Paleontologii. Zastanawiający jest fakt posiadania dwóch egzemplarzy jedynie drugiego tomu. $\mathrm{Z}$ jednej strony - jak wiadomo - w przypadku bogato ilustrowanych dzieł przyrodniczych w drugiej połowie XVIII i pierwszej XIX w. zdarzało się, iż

25 Zob. A. Rickiene, Exercitia phytologica (1792) by J. E. Gilibert in European libraries, „Archives of Natural History” 2015, t. 42, nr 1, s. 178-181.

26 Zob. P. Daszkiewicz, Polonika w archiwum Georga Cuviera, „Przegląd Zoologiczny” 1998, z. 3-4, s. 207-209. 
wydawano najpierw ikonografię 27 , by zdobyć w ten sposób środki materialne na wydanie części z tekstem, cieszących się znacznie mniejszym popytem niż same ilustracje. Niekiedy nakład ikonografii był wyższy niż opisów. Być może zatem zakupiono jedynie drugi tom, gdyż wiedziano, że część z ilustracjami - przysłana G. Cuvierowi przez L.H. Bojanusa - znajduje się już w muzealnej kolekcji. Z drugiej strony nie jest wykluczonym, że pierwsza, ikonograficzna część, szczególnie cenna, po prostu - jak wiele innych muzealnych dokumentów - zaginęła. Biblioteka Główna posiada także egzemplarz innej pracy L.H. Bojanusa, będącej kontynuacją monografii o anatomii żółwia: Parergon ad L.H. Bojani Anatomen testudinis: cranii vertebratorum animalium, scilicet piscium, reptilium, avium, mammaliium comparationem faciens, icone illustratam: in usum studiosae juventutis seorsum excusum, także wydanej z ilustracjami F.L. Lehmanna przez K. Zawadzkiego w Wilnie w 1821 r. Egzemplarz zawiera adnotacje ołówkiem i poprawki rysunków anatomicznych, wykonane prawdopodobnie ręką G. Cuviera.

We Francji egzemplarz dzieła L.H. Bojanusa posiada także Narodowa Biblioteka Uniwersytecka (Bibliothèque nationale et universitaire) w Strasburgu; drugi egzemplarz przechowywany jest w bibliotece Fakultetu Medycyny. Przed dwoma laty rozprawa ta była wystawiana w Muzeum Toni Ungerera (Musée Tomi Ungerer - Centre international de l'Illustration), wybitnego alzackiego artysty, znanego także z ilustracji zwierząt. Biblioteka Uniwersytetu (Bibliothèque Universitaire des sciences et techniques) w Montpellier także ma oryginalne wileńskie wydanie Anatome testudinis europaeae. Warto przy tym pamiętać nie tylko o ogromnym znaczeniu szkoły przyrodniczej z Montpellier, lecz także o jej ścisłych związkach z Wilnem. Ogród botaniczny i fakultet tej uczelni stanowiły przecież model dla Uniwersytetu Wileńskiego w momencie organizacji nauczania przyrodoznawstwa ${ }^{28}$.

W Wilnie dr Grita Skujienè, kustosz zoologicznej kolekcji uniwersyteckiego muzeum, pokazała autorom egzemplarz będący prawdopodobnie własnością L.H. Bojanusa. Prawdopodobnie - albowiem podobnie jak i w przypadku okazów przyrodniczych, także żółwi błotnych pochodzących z początków XIX w., popowstaniowy rabunek uniwersyteckich zbiorów i dokumentacji w 1832 r. uniemożliwia dokładne ustalenie historii tego egzemplarza.

W Polsce egzemplarze Anatome testudinis europaeae posiadają: BUW, Biblioteka Książąt Czartoryskich oraz Muzeum i Instytut Zoologii PAN.

27 Autorzy dziękują prof. Pietro Corsiemu za informacje dotyczące podobnych praktyk w przypadku dziewiętnastowiecznych ilustrowanych wydań prac Georges’a-Louisa Leclerca, hrabiego Buffon (1707-1788).

${ }_{28}$ Zob. P. Daszkiewicz, List Jean-Emmanuel Giliberta (1741-1814) z Grodna do AntoineLaurent de Jussieu (1748-1836) - nieznany, interesujacy dokument historii nauk przyrodniczych w Rzeczypospolitej, „Kwartalnik Historii Nauki i Techniki” 2015, z. 3-4, s. 211-221. 
Ta ostatnia instytucja, mimo iż szczyci się jedną z najważniejszych historycznych bibliotek zoologicznych w Europie Środkowej29, zakupiła dzieło dopiero w 1949 r. ${ }^{30}$ Egzemplarz z Biblioteki Czartoryskich został przeanalizowany przez J. Jakubowskiego ${ }^{31}$.

Niewątpliwie interesujące będą rezultaty ankiety przeprowadzonej w Rosji. W Archiwum Rosyjskiej Akademii Nauk w Sankt Petersburgu (СанктПетербургский Филиал Архива Российской Академии Наук - SPFARAN) znajduje się część korespondencji L.H. Bojanusa i liczne dokumenty związane $\mathrm{z}$ jego karierą naukową ${ }^{32}$. Autorzy mają nadzieję, że rozesłanie formularzy do rosyjskich bibliotek i instytucji doprowadzi do ustalenia losów przynajmniej kilkunastu egzemplarzy Anatome testudinis europaeae.

Prof. Jacek Puchalski przekazał autorom informacje (na podstawie opisów zamieszczonych w WorldCat ${ }^{33}$ ) o egzemplarzach poszukiwanego dzieła L.H. Bojanusa znajdujących się w niemieckich bibliotekach: Państwowej (Staatsbibliothek) w Berlinie, Uniwersyteckiej i Krajowej (Universitäts- und Landesbibliothek Sachsen-Anhalt) w Halle, Uniwersyteckiej (Universitätsbibliothek - Bibliotheca Albertina) w Lipsku, Uniwersyteckiej (Universitätsbibliothek) w Tybindze oraz Uniwersyteckiej i Krajowej (Thüringer Universitäts- und Landesbibliothek) w Jenie. Szczególnie interesujący może okazać się egzemplarz z Jeny -z uwagi na bliskie związki, jakie łączyły L.H. Bojanusa z Lorenzem Okenem (1779-1851), niemieckim przyrodnikiem i wydawcą czasopisma „Isis”, w którym alzacki uczony regularnie publikował swoje prace. To zapewne także w Niemczech, z racji na liczne kontakty naukowe L.H. Bojanusa ${ }^{34}$, istnieje największe prawdopodobieństwo odnalezienia egzemplarzy Anatome testudinis europaeae w kolekcjach prywatnych. Dodatkowe poszukiwania zostaną przeprowadzone także w Darmstadt. W mieście tym znalazły się przecież niewydane rękopisy L.H. Bojanusa, m.in. jego monografia owcy z 500 ilustracjami ${ }^{35}$, która zgodnie z ostatnią wolą uczonego trafiła do jego siostrzeńca Wilhelma Eigenbrodta, a także część preparatów, które służyły do przygotowania inwentaryzowanej publikacji, a nawet okaz spreparowanego żółwia błotnego, przesłany z Wilna w prezencie księciu heskiemu. Ogromne zniszczenia, jakich doznało to miasto w czasie dywanowego nalotu 11 i 12 września 1944 r., zapewne nie oszczędziły i części dziedzictwa L.H. Bojanusa.

29 Zob. W. Laszczukowska, Zarys rozwoju Biblioteki Instytutu Zoologicznego Polskiej Akademii Nauk, Wrocław-Warszawa-Kraków 1965.

30 Autorzy dziękują prof. Dariuszowi Iwanowi za informacje na temat tego egzemplarza.

31 Zob. J. Jakubowski, dz. cyt., s. 51.

32 Autorzy dziękują dr Anastazji Fedotowej z Instytutu Historii Nauki i Technologii Rosyjskiej Akademii Nauk za informacje na temat dokumentów L.H. Bojanusa w Petersburgu.

33 Zob. [online] <https://www.worldcat.org/> (03.12.2016).

34 Przypis redakcji: także z powodu przekazania części nakładu F. Fleischerowi z Lipska i być może L.F. von Froriepowi z Weimaru.

35 Zob. Z. Fedorowicz, dz. cyt., s. 23. 
Od kilku lat dzieło alzackiego przyrodnika jest dostępne on-line - jego skany zamieściła przodująca w dziedzinie cyfryzacji prac przyrodniczych - amerykańska Biodiversity Heritage Library. Zdigitalizowany egzemplarz pochodzi z Ernst Mayr Library Museum of Comparative Zoology Uniwersytetu Harvarda. Drugą instytucją, która udostępniła on-line swój egzemplarz Anatome testudinis europaeae, jest biblioteka uniwersytecka (Universitätsbibliothek) w Bazylei. W Stanach Zjednoczonych książkę L.H. Bojanusa posiada, pozostający w kontakcie z autorami, prof. Kraig Adler z Cornell University, wybitny znawca historii herpetologii i wydawca reprintu z 1970 r. Interesującą i dotychczas nieznaną historykom nauki informację udało się otrzymać od niemieckiego herpetologa i kolekcjonera dr Thomasa Schöttlera, który jest właścicielem egzemplarza z kolorowymi ilustracjami, będącego uprzednio, jak wskazuje stempel, własnością Biblioteki Brytyjskiego Towarzystwa Medycznego (British Medical Association Library). Nie wiadomo jaka część nakładu i dlaczego została wydana z kolorowymi ilustracjami. Zdaniem dr T. Schöttlera nie ulega wątpliwości, iż chodzi o kolor pochodzący z oryginalnego druku, a nie o ilustracje pokolorowane już po publikacji. Drugi znany „kolorowy” egzemplarz znajduje się w Stanach Zjednoczonych w zbiorach biblioteki uniwersyteckiej (Kenneth Spencer Research Library) w Kansas.

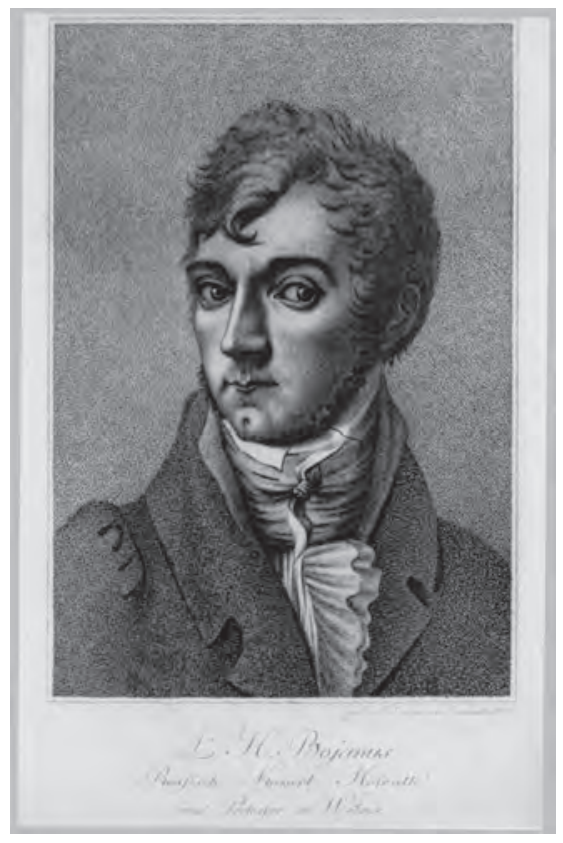

Fot. 1. Portret datowany na 1809 r., narysowany i ryty w Darmstadt przez F.L. Lehmanna, Archiwum firmy Merck. Zdjęcie: P. Edel

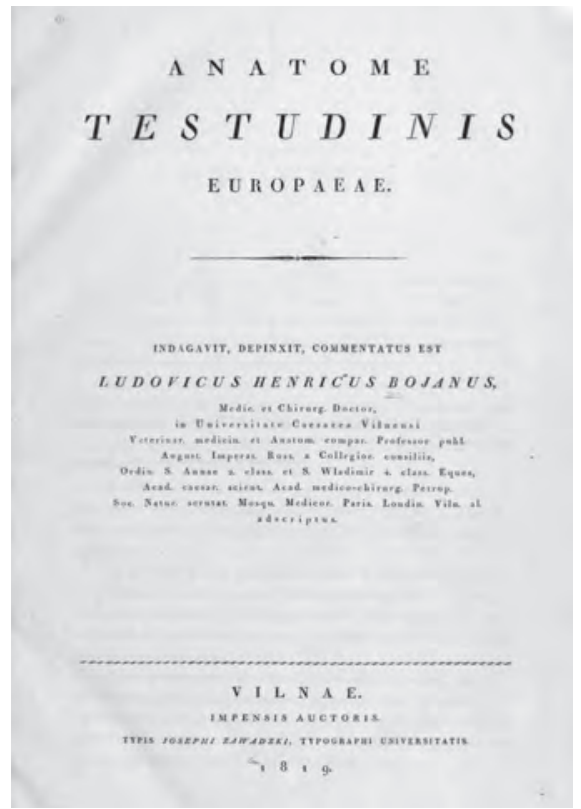

Fot. 2. Strona tytułowa Anatome testudinis europaeae. Zdjęcie: P. Edel 


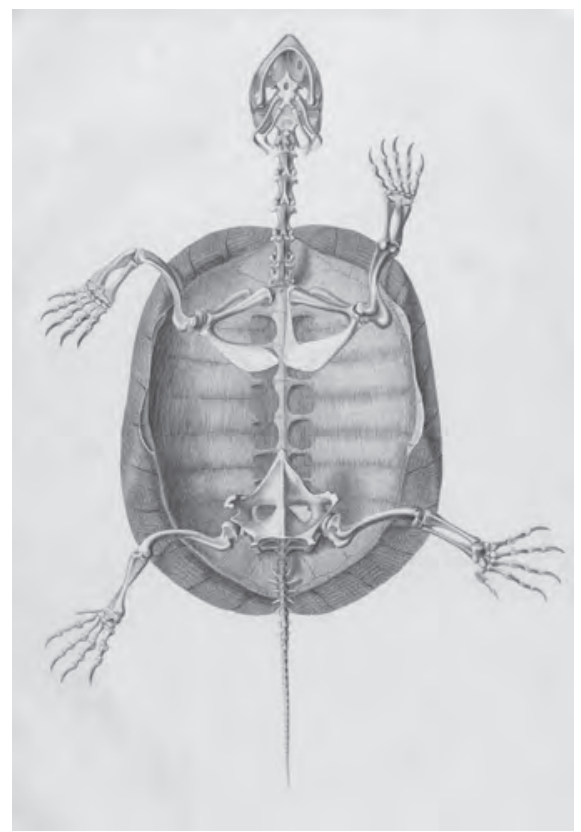

Fot. 3. Ilustracja z Anatome testudinis europaeae. Zdjęcie: P. Edel

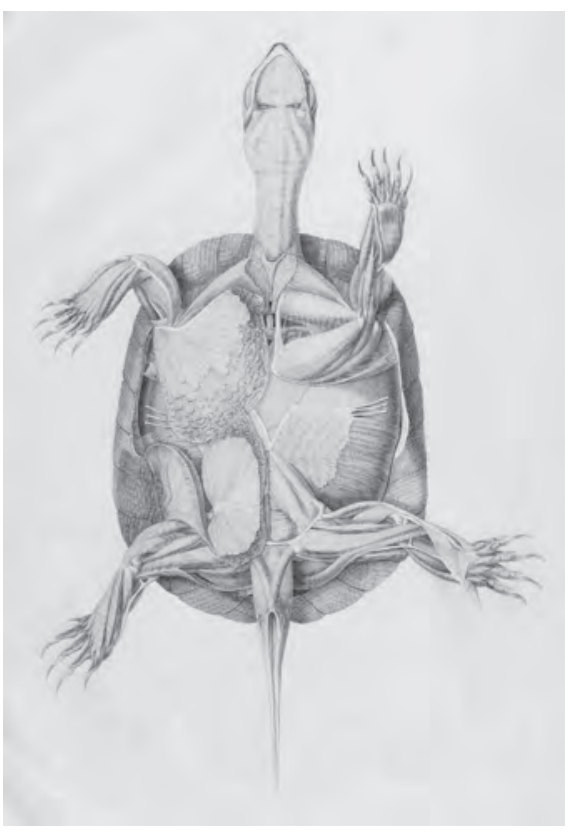

Fot. 4. Ilustracja z Anatome testudinis europaeae. Zdjęcie: P. Edel

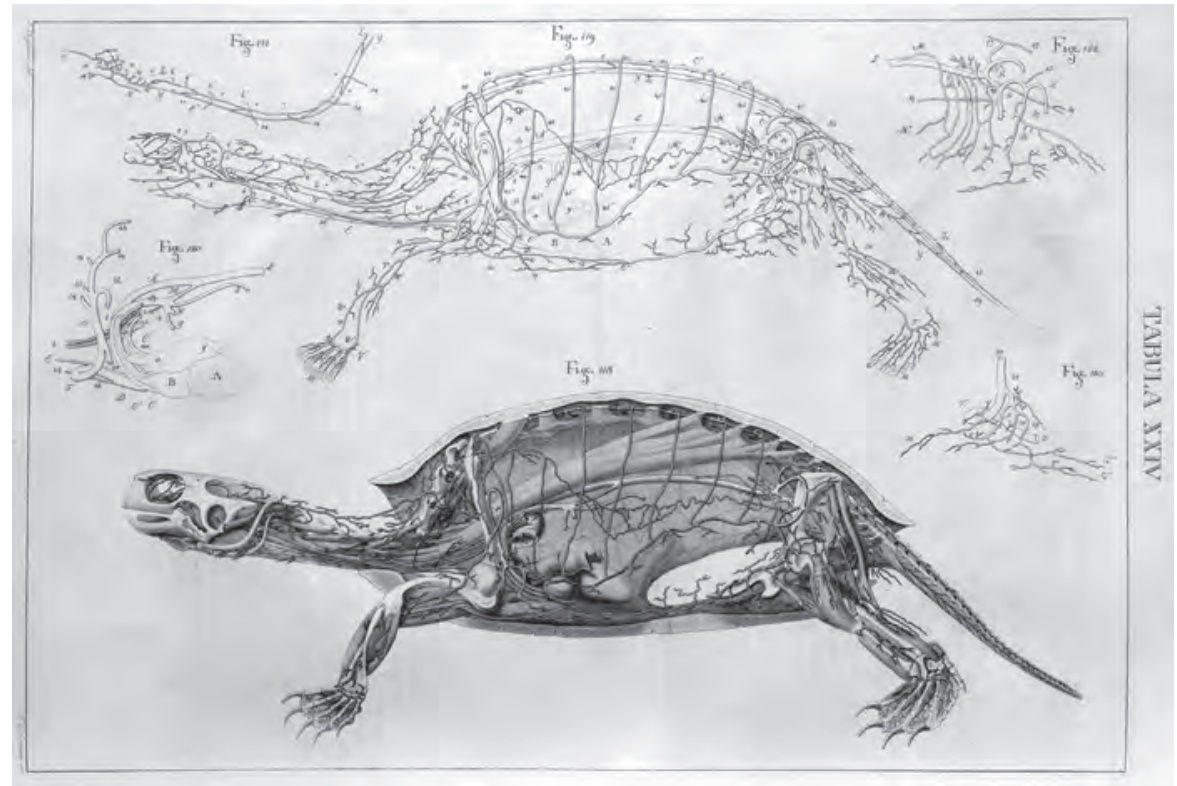

Fot. 5. Ilustracja z kolorowej wersji Anatome testudinis europaeae ze zbiorów dr. Thomasa Schöttlera. Zdjęcie: T. Schöttler 


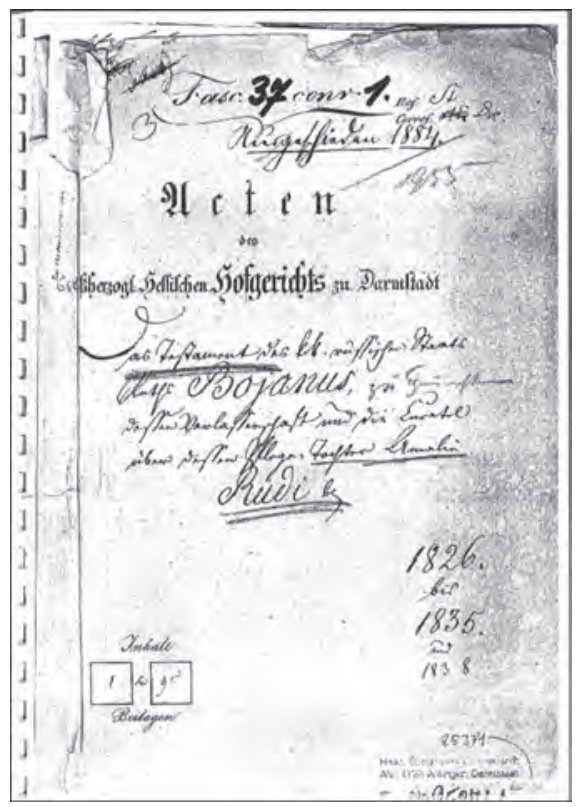

Fot. 6. Pierwsza strona testamentu L.H. Bojanusa, Archiwa Państwa Heskiego w Darmstadt. Zdjęcie: P. Edel

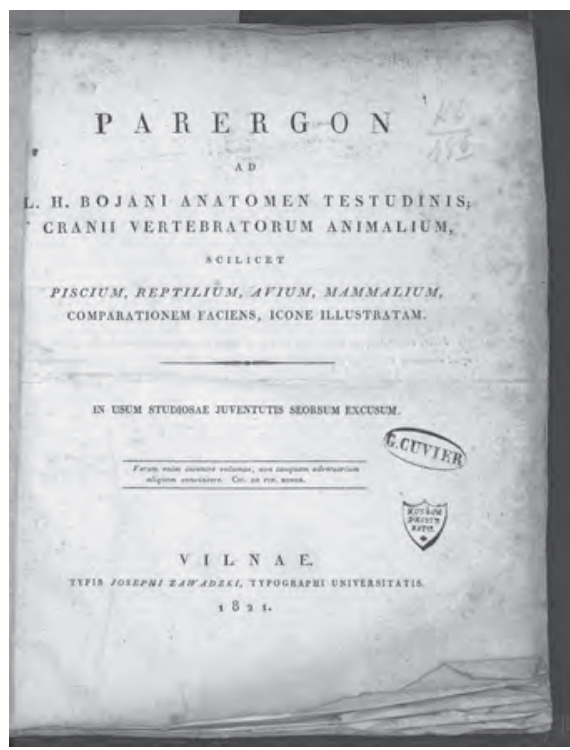

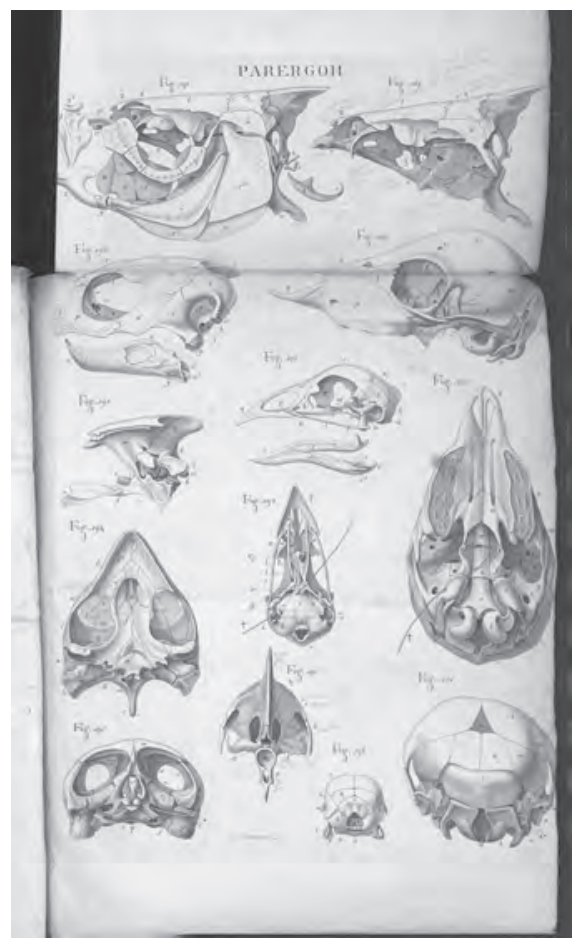

Fot. 7. Strona Parergon... z adnotacjami prawdopodobnie autorstwa G. Cuviera, Biblioteka

Główna Narodowego Muzeum Historii

Naturalnej, skan wykonany w Bibliotece Głównej MNHN na prośbę P. Daszkiewicza

Fot. 8. Strona tytułowa Parergon... z egzemplarza należącego kiedyś do G. Cuviera, Biblioteka Główna Narodowego Muzeum Historii Naturalnej, skan wykonany w Bibliotece Głównej MNHN na prośbę P. Daszkiewicza 
Autorzy mają nadzieję, że wyniki ankiety pozwolą na lepsze poznanie historii jednego z najważniejszych dzieł dziewiętnastowiecznej zoologii, jakim była Anatome testudinis europaeae. Być może oprócz ustalenia lokalizacji egzemplarzy uda się także odtworzyć dzieje reszty nakładu wzmiankowanego w testamencie L.H. Bojanusa, jak i miedzianych płyt, które posłużyły do druku. Być może publikacja niniejszego tekstu przyczyni się także do odnalezienia egzemplarzy dzieła L.H. Bojanusa w kolejnych polskich bibliotekach i kolekcjach.

\section{Streszczenie}

Towarzystwo Cercle d'Histoire Alsace-Lituanie od kilku lat prowadzi akcję uzupełniania i popularyzacji wiedzy o Ludwiku Henryku Bojanusie (1776-1827), alzackim przyrodniku i profesorze Uniwersytetu Wileńskiego. Jednym z elementów tej akcji jest poszukiwanie w europejskich i amerykańskich bibliotekach egzemplarzy Anatome testudinis europaeae, opus vitae L.H. Bojanusa, a zarazem jednej z najważniejszych zoologicznych książek XIX w. W 2017 r. zostanie rozesłana do bibliotek ankieta. Autorzy uzyskali już informacje na temat egzemplarzy w bibliotekach w Paryżu, Strasburgu, Montpellier, Warszawie i Wilnie, a także egzemplarza z kolorowymi ilustracjami znajdującego się w zbiorach prywatnych w Niemczech.

Słowa kluczowe: Ludwik Henryk Bojanus - historia książek zoologicznych - Anatome testudinis europaeae - Uniwersytet Wileński, XIX w.

\section{Summary}

\section{The search for copies of the Anatome testudinis europaeae in European and American libraries}

For several years now, Cercle d'Histoire Alsace-Lithuania has been carrying out an action aimed at complementing and popularizing knowledge about Ludwik Henryk Bojanus (1776-1827), an Alsatian naturalist and professor at the University of Vilnius. The search for copies of Anatome testudinis europae, the work of Bojanus' life and one of the most important zoological books of the nineteenth century in European and American libraries is one of the elements of this action. A detailed form will be sent to libraries in 2019. The authors have already obtained information on the copies in libraries in Paris, Strasbourg, Montpellier, Warsaw and Vilnius and also about a copy with coloured illustrations from a private collection in Germany.

Key words: Bojanus - history of zoological books - Anatome testudinis europae - Vilnius University $-19^{\text {th }}$ century. 